\title{
Geomorphological explanation of karstic drainage sensitivity toward anthropogenic pollutants in Kardeh catchment, NE Iran
}

\author{
Mohammad Reza Mansouri Daneshvar", Abolfazl Behniafar, Hadi Ghanbarzadeh \\ Department of Physical Geography, Mashhad Branch, Islamic Azad University, Mashhad, Iran \\ Email address: \\ mrm_daneshvar2012@yahoo.com (M. R. M. Daneshvar)
}

To cite this article:

Mohammad Reza Mansouri Daneshvar, Abolfazl Behniafar, Hadi Ghanbarzadeh. Geomorphological Explanation of Karstic Drainage Sensitivity toward Anthropogenic Pollutants in Kardeh Catchment, NE Iran. International Journal of Environmental Protection and Policy. Vol. 2, No. 3, 2014, pp. 113-117. doi: 10.11648/j.ijepp.20140203.12

\begin{abstract}
In the present study, we aimed to geomorphological explanation of karst features and their environmental sensitivity in Kardeh catchment in Kopet-Dagh mountainous zone, NE Iran. Environmental sensitivity of karst is well marked by anthropogenic pollutants and land degradation problems in regions such as Kopet-Dagh, where some tens of karstic landforms are present over the Jurassic lithology. Anthropogenic pollutants resulted in intense environmental degradation and changed the natural karstic drainage in the catchment. We faced with karstified drainage, which supplies a portion of drinking-water of Mashhad metropolitan area. In Kardeh catchment, three main sources of anthropogenic pollutants to karst drainage have been identified: agricultural impacts, waste water entrance in hydrologic system of karst and garbage burying on carbonate prone rocks. Based on the comparison of fertilizers consumption and wastes production in the catchment we observed that the sub-basins of Balghur (Bl), Kharkat (Kh) and Mareshk (Ma) sub-basins have the most anthropogenic pollutants, where the carbonate formations of Mozduran 1, 2 (>75\% of surface area) have the most environmental sensitivity. As a general rule, the protection of the hydrologic system of karst and management of the carbonate catchment are geomorphological strategies in environmental planning.
\end{abstract}

Keywords: Anthropogenic Pollutants, Environmental Sensitivity, Geomorphology, Kardeh Catchment, Karstic Drainage

\section{Introduction}

Usually, the hydrologic systems of karst create a number of engineering and environmental problems that will probably increase as development extends over the populated areas (Ford 1993, Johnson and Neal 2003, Gutiérrez et al. 2008). Spatial construction on karst lithology and porous-prone areas is the main sensitivity for engineers. Furthermore, the karst drainage dependence of drinking-water supply in many populated areas is still a challenging issue for the geoscientists and environmental planners. Because karst covers 10 to $20 \%$ of the earth's surface and provides 40 to $50 \%$ of the world's drinking-water (Ford and Williams 2007, White 2007), it requires a specific approach to mitigate negative anthropogenic impacts and allow sustainable development. In this sense, protection of karst water is essential in many countries. Hydrologic system of karst is highly vulnerable to pollution and land use changes (Drew and Hötzl 1999, Bakalowicz 2005, Calò and Parise 2009). The characteristics and behavior of karst systems, largely due to their significant and peculiar drainage, commonly have a significant degree of uncertainty (Milanovic 2000). However, a good knowledge of the karst components and their complex interrelationship is the basis for the proper planning and application of development and conservation strategies. Karst waters are characterized by a dual or even triple porosity and permeability (Liedl et al. 2003, Gabrovsek et al. 2004) and sometimes also through inter granular pores (Daly et al. 2002). In the present study, we aimed to geomorphological explanation of karst features and their environmental sensitivity in Kardeh catchment in Kopet-Dagh mountainous zone, NE Iran. Hydrologic system of karst in Kardeh catchment has a high sensitivity to anthropogenic pollutants. Thus, some anthropogenic factors including garbage burying in karst holes, entrance of wastewater and sewages and agricultural effects including of chemical fertilizers and poisons to hydrologic system of karsic drainage in this region, have caused to the land degradation and water pollution. 


\section{Material and Methods}

\subsection{Geographical Position of the Study Area}

The Kardeh catchment is located in Kopet-Dagh mountainous zone, NE Iran (Fig. 1). The catchment that is belonged between $36^{\circ} 37^{\prime} \sim 36^{\circ} 58^{\prime} \mathrm{N}$ and $59^{\circ} 26^{\prime} \sim 59^{\circ} 44^{\prime} \mathrm{E}$ consists of 7 sub-basins with the total surface area of about $555 \mathrm{Km} 2$ and the total main stream length of $45 \mathrm{Km}$. The terrain elevation varies between $1200 \mathrm{~m}$ a.s.l at the south and $2977 \mathrm{~m}$ a.s.l at the north, with a dominance over $1800 \mathrm{~m}$ a.s.l (Fig. 2a). The terrain drainage of catchment is patterning of the some parallel dendrites, which are reflected the intrinsic karst morphology (Fig. 2b). The study area is featured by the semi-arid climate with the mean annual precipitation of 322 $\mathrm{mm}$ and the mean annual temperature of $11.8^{\circ} \mathrm{C}$ (Bagherzadeh and Mansouri Daneshvar 2011). Also, the Kardeh Dam Lake with an area of 200 ha at $1200 \mathrm{~m}$ a.s.1, is located at the south part of catchment. The mean annual volume of Kardeh Dam Lake is about 28 million cubic meters (Fig. 3). This karst water reservoir consists of about 5 to 10 percent of drinking-water supply of Mashhad metropolitan area with $2,800,000$ populations, which is located in southward with $40 \mathrm{Km}$ distance.

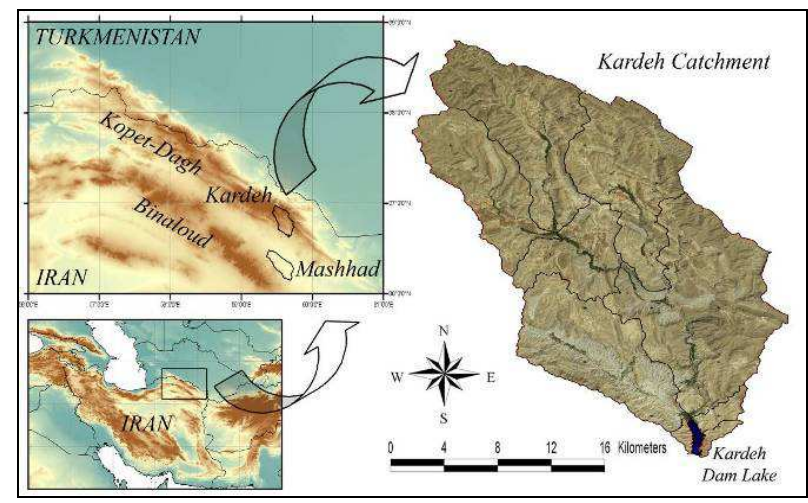

Figure 1. The geographical position of Kardeh catchment in Kopet-Dagh mountainous zone, NE Iran.

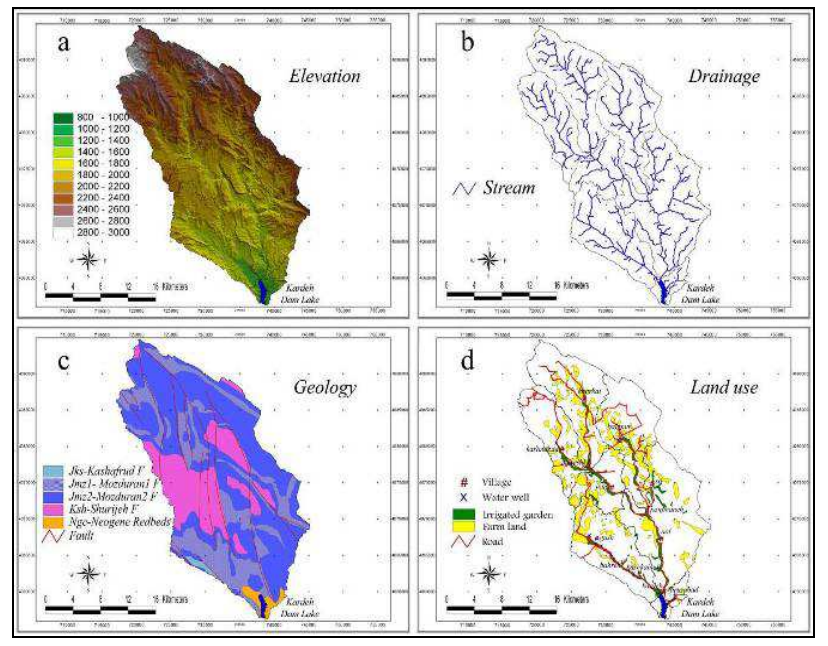

Figure 2. The terrain elevation (a), drainage (b), geology (c) and land use (d) maps of Kardeh catchment.

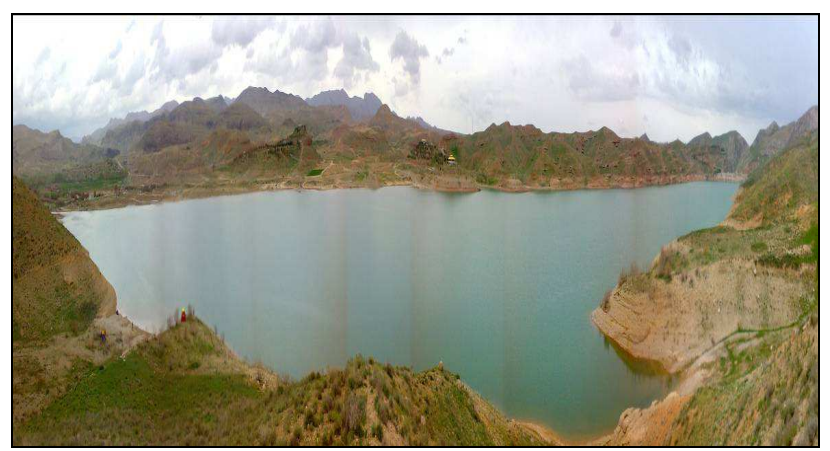

Figure 3. General landscape of Kardeh Dam Lake, view of west to east.

\subsection{Methodology}

In the Kardeh catchment, several events of degradation have damaged the natural environments in the last decades. In the recent years, rare information exist to document and quantitative evaluation of the karst phenomena, which include degradation, deforestation, land use changes and the consequent increase in erosion and loss of water quality. Now, application of GIS techniques and field operations especially is clearly demonstrated the effective factors of water pollutions in karst systems. In this regard, topographical, geological and land use of rural settlements as the environmental layers are prepared in GIS. Therefore, all of the analytical explanations as well known from experiences in worldwide karst regions lead us to the overall investigation of environmental sensitivities. In the same research, Kovačič and Ravbar (2005) have reviewed the potential and actual sources of pollution to the karst water in the Slovenian karst areas. Therefore, Parise et al. (2008) have assessed the influences of evaporate karst on natural landscapes, hydrological aquifers and environmental pollutions in Albanian karst regions.

\section{Results and Discussion}

\subsection{Geological Survey of the Study area}

To accurate geological survey of the study area, the catchment is subdivided into homogeneous lithological units based on the interpretation of 1:100,000 geological maps and field observations (Fig. 2c). The study area is covered mainly by carbonate formation and evaporative members $(>75 \%$ of surface area), such as Jurassic dolomite and lime shale. The oldest rock units observed at the study area is Jurassic limestone of the Kashafrud formation and the youngest is Neogene red conglomerate. Distributions of geological formations are shown in Table 1. Also, the catchment develops several micro-faults, formed mainly by alternations of sandstone and shale. Karst valleys in eastern part of Kopet-Dagh zone due to combine with alteration layers are usually powerless in water filtration. Then there are the vast networks of fissures on carbonate rocks and very high porosity such as karst shafts and caves, which are illustrated in Fig. 4. 
Table 1. Geological formations and main lithology of Kardeh catchment.

\begin{tabular}{|c|c|c|c|c|}
\hline \multirow{2}{*}{ Formation } & \multirow{2}{*}{ Symbol } & \multirow{2}{*}{ Main lithology } & \multicolumn{2}{|c|}{ Area } \\
\hline & & & $\mathbf{K m}^{2}$ & $\%$ \\
\hline Kashafrud & Jks & $\begin{array}{l}\text { Sandstone, shale, } \\
\text { siltstone }\end{array}$ & 5 & 0.90 \\
\hline Mozduran1 & Jmz1 & $\begin{array}{l}\text { Alternation of } \\
\text { limestone and shale }\end{array}$ & 148 & 26.67 \\
\hline Mozduran2 & Jmz2 & $\begin{array}{l}\text { Limestone thick } \\
\text { bedded, dolomite }\end{array}$ & 282 & 50.81 \\
\hline Shurijeh & Ksh & $\begin{array}{l}\text { Gypsum, brown } \\
\text { marl, siltstone }\end{array}$ & 112 & 20.18 \\
\hline Neogene & $\mathrm{Ngc}$ & $\begin{array}{l}\text { Conglomerate, marl, } \\
\text { mudstone }\end{array}$ & 8 & 1.44 \\
\hline Total & & & 555 & 100 \\
\hline
\end{tabular}

Furthermore, anthropogenic pollutants in hydrologic system of karst are transferred faster than non-karst areas to carbonate aquifers. The penetration of rainfall and waste water into drainage of springs and wells are occurred in the catchment, where about 65 percent of the surface area has been covered by karstic landforms. As a result, karstification process has been intensified by the dissolution of calcite $(\mathrm{CaCO} 3)$ and dolomite $(\mathrm{CaMg}(\mathrm{CO} 3) 2)$ rocks (Das and Kaur 2001) in Mozdouran 1, 2 formations as following formulates of 1 and 2:

$$
\begin{gathered}
\mathrm{CaCO}_{3}+\mathrm{H}_{2} \mathrm{CO}_{3} \leftrightarrow \mathrm{Ca}^{+2} 2 \mathrm{HCO}_{3} \\
\mathrm{CaMg}\left(\mathrm{CO}_{3}\right)_{2}+2 \mathrm{H}_{2} \mathrm{CO}_{3} \leftrightarrow \mathrm{Ca}^{+2}+\mathrm{Mg}^{+2}+4 \mathrm{HCO}_{3}
\end{gathered}
$$

Karst features including linear and vacuolar forms, funnel-shaped Karst Shafts, Holes and Caverns and polygenic features are chiefly formed in these formations. Furthermore, surface karst geomorphology and water drainage is characterized by a number of Ponors, Dolines, Karrens, Avens and Sinkholes, which often correspond to lines and points of terrain drainage and caves (Table 2).

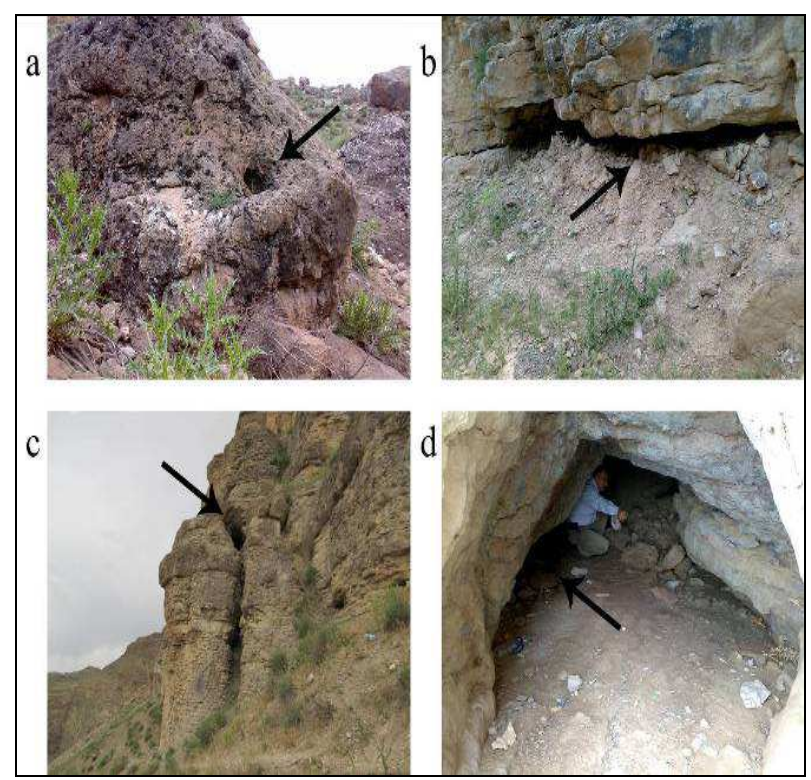

Figure 4. The networks of fissures on carbonate rocks and porosity such as karst shafts and caves.

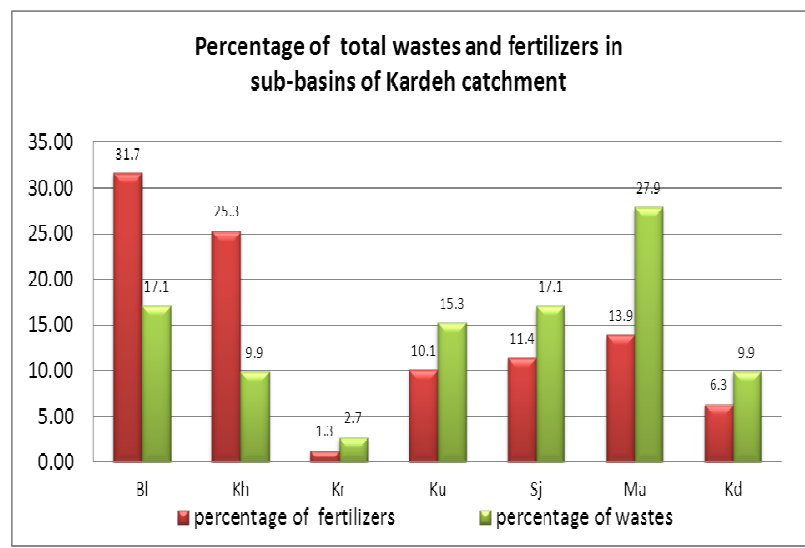

Figure 5. The percentage of total wastes and fertilizers in sub-basins of Kardeh catchment.

\subsection{Anthropogenic Pollutants}

About 13 rural settlements with sum about of 5550 populations are scattered along main streams in 7 sub-basins of Kardeh catchment (Fig. 2d), which annually release in natural drainage waste water and waste matter of 202,575 $\mathrm{m} 3$ and $607,725 \mathrm{~kg}$, respectively (Table 3). The mentioned sub-basins are prospered about of 7900 ha cultivated areas and farm lands, which use the 7110 ton and 2370 ton of manure and chemical fertilizers, respectively (Table 4). The most important evidence of water pollution from anthropogenic impacts is the presence of nitrates and pesticides (León and Parise 2009).

Table 2. Geomorphological characteristics of karstic landforms in the study

\begin{tabular}{|c|c|c|c|}
\hline No. & $\begin{array}{l}\text { Karstic } \\
\text { landforms }\end{array}$ & Natural environment & $\begin{array}{l}\text { Anthropogenic } \\
\text { degradation }\end{array}$ \\
\hline 1 & Linear Karren & $\begin{array}{l}\text { Along minor joints, veins, } \\
\text { micro fractures and micro } \\
\text { faults }\end{array}$ & $\begin{array}{l}\text { Conduct line of } \\
\text { cultivation and } \\
\text { irrigation }\end{array}$ \\
\hline 2 & $\begin{array}{l}\text { Sinkholes } \\
\text { Ponors }\end{array}$ & $\begin{array}{l}\text { Surface depression on } \\
\text { Epi-karst and Endo-karst } \\
\text { landforms }\end{array}$ & $\begin{array}{l}\text { Water pollution } \\
\text { transmission }\end{array}$ \\
\hline 3 & $\begin{array}{l}\text { Funnel } \\
\text { Shaped Aven }\end{array}$ & $\begin{array}{l}\text { Water dropping and leakage } \\
\text { on collapsed carbonate }\end{array}$ & $\begin{array}{l}\text { Waste water and } \\
\text { chemical fertilizers }\end{array}$ \\
\hline 4 & Caves & Natural underground space & $\begin{array}{l}\text { Non-organic and } \\
\text { solid trashes placing }\end{array}$ \\
\hline 5 & $\begin{array}{l}\text { Karst Shafts } \\
\text { Dolines }\end{array}$ & $\begin{array}{l}\text { Surface depression on } \\
\text { Epi-karst and Endo-karst } \\
\text { landforms }\end{array}$ & Livestock pollutions \\
\hline
\end{tabular}
are.

Table 3. The annual release of waste water and waste matter in drainage of Kardeh catchment by rural settlements.

\begin{tabular}{cccccc}
\hline No. & Sub-basin & $\begin{array}{c}\text { Rural } \\
\text { settlements }\end{array}$ & Population & $\begin{array}{c}\text { Waste } \\
\text { water (m3) }\end{array}$ & $\begin{array}{c}\text { Waste } \\
\text { matter (kg) }\end{array}$ \\
\hline 1 & Balghur & 1 & 950 & 34675 & 104025 \\
5 & Kardeh Dam & 2 & 500 & 20075 & 60225 \\
6 & Karimabad & 1 & 100 & 5475 & 16425 \\
7 & Kharkat & 1 & 550 & 20075 & 60225 \\
8 & Kushkabad & 3 & 800 & 31025 & 93075 \\
9 & Mareshk & 2 & 1450 & 56575 & 169725 \\
10 & Sijoal & 3 & 850 & 34675 & 104025 \\
$\#$ & Total & 13 & 5550 & 202575 & 607725 \\
\hline
\end{tabular}


Table 4. The annual consumption of manure and chemical fertilizers in drainage of Kardeh catchment by cultivation areas.

\begin{tabular}{|c|c|c|c|c|c|}
\hline \multirow{2}{*}{ No. } & \multirow{2}{*}{ Sub-basin } & \multirow{2}{*}{$\begin{array}{c}\text { Rural } \\
\text { settlements }\end{array}$} & \multirow{2}{*}{$\begin{array}{l}\text { Cultivated } \\
\text { areas (ha) }\end{array}$} & \multicolumn{2}{|c|}{ Fertilizers (ton) } \\
\hline & & & & Manure & Chemical \\
\hline 1 & Balghur & 1 & 2500 & 2250 & 750 \\
\hline 5 & Kardeh Dam & 2 & 500 & 450 & 150 \\
\hline 6 & Karimabad & 1 & 100 & 90 & 30 \\
\hline 7 & Kharkat & 1 & 2000 & 1800 & 600 \\
\hline 8 & Kushkabad & 3 & 800 & 720 & 240 \\
\hline 9 & Mareshk & 2 & 1100 & 990 & 330 \\
\hline 10 & Sijoal & 3 & 900 & 810 & 270 \\
\hline \# & Total & 13 & 7900 & 7110 & 2370 \\
\hline
\end{tabular}

Anthropogenic pollutants including penetration of settlement sewage into rivers, burying of garbage and waste matter in karst landforms, penetration of waste waters and animal excrement into drainage water and ground water reservoirs reduce the quality of water supply of Kardeh Dam Lake. Based on the comparison of fertilizers consumption and wastes production in the catchment we observed that the sub-basins of Balghur (Bl), Kharkat (Kh) and Mareshk (Ma) sub-basins have the most anthropogenic pollutants, where the carbonate formations of Mozduran 1, 2 have the most environmental sensitivity (Fig. 5). In the previous research on Kardeh catchment, Bagherzadeh and Mansouri Daneshvar (2011) have revealed that the mentioned sub-basins were involved the heavy class of annual specific production of sediments. More than 90 percent of drinking-water that is necessary for rural settlements of Kardeh catchment is provided by karstic water supply. Therefore, the entrance of pollutants to carbonate aquifers and karst drainage system in this area can have a direct effect on people health. A portion of the drinking-water of Mashhad metropolitan area is provided by water supply of Kardeh catchment.

\section{Category of Potential Pollutants}

Karst environments and particularly karst drainage are extremely fragile and sensitive, so that anthropogenic changes may induce unwanted effects in short periods of time (Parise and Gunn 2007). In karst hydrology system, the intrinsic vulnerability of the environment makes it highly susceptible to pollution, which may result in dramatic consequences for both the quality of karst water and the amount of water available. Many anthropogenic impacts produce negative changes in the karst aquifers with significant effects (Van Beynen and Townsend 2005, Calò and Parise 2006, Van Beynen et al. 2007, North et al. 2009). In this study, we showed some different types of potential pollutants on karstic drainage. In Kardeh catchment, three main sources of anthropogenic pollutants to karst drainage have been identified: agricultural impacts, waste water and garbage burying.

\subsection{Agricultural Impacts}

Agricultural effects are included of chemical fertilizers and poisons to hydrologic system of karstic drainage. Main impact is the entrance of pollutant flows with fertilizers and chemical poisons from irrigated farming and traditional cultivations into the main streams as well as Dam Lake. Therefore, traditional livestock wastes have important role in deteriorating of karst water quality especially springs.

\subsection{Waste Water}

Entrance of waste water in hydrologic system of karst, transmission of detergents by rural settlements and transfer of sewage by karstic conduits without any water filtration into carbonate drainage is one of pollution source in the study area. About $65 \%$ of absorptive wells are placed on sinkholes and karst shafts that resulted on soil loss and sedimentation. The mentioned factor is a dangerous part of water pollutions and environmental hazards in Lang-term.

\subsection{Garbage Burying}

Garbage burying on carbonate prone rocks, sinkholes and caves by rural settlements consist of fruit peel and vegetables, plastic and disposable materials, metallic material, glass bit, food stuffs remains and charcoal.

\section{Conclusions}

Based on field observations, the karst dolines, sinkholes, and caves are used for garbage burying and waste matters. According to the fields survey of the karst shaft in upper areas of catchment, various rubbish materials as remainders of plastic materials, nitrous rubbish and pile of carpet wearing were buried into the karstic landforms. Throwing away rubbish and trash by tourists around kardeh dam and route of upstream rivers have intensified water pollution risk. Raining infiltration and snow melting have caves decomposing and deterioration of trash in karst shafts and with penetrating runoff into hydrologic system of karst is one of the important sources of water pollution. Based on the results, the geomorphological strategies of karst management are essential in Iran because there is not the clear perspective related to the karst management and environmental sensitivity. Legislation on the karst water protection on the country will play a vital role in this case. The monitoring laws in the karstic zones of Iran especially in the mountainous karsts of Zagros, Alborz and Kopet-Dagh are required to effective environmental management.

\section{Suggestions}

A number of strategies in this case are as follows: utilization of dustbins to collect trash gathering and to prevent throwing rubbish in sinkholes or rubbish burring, gathering of rural sewage by septic tanks and sewerage services, prevention of domestic animal wastes in karstic phenomena, protection of the dam lake, karstic springs and sub-stream routes in catchment drainage and hydrogeological planning of warning boards in order to 
water pollution risk management. As experienced in other countries (Emmett and Telfer 1994, Parise et al. 2004) these strategies strongly prevented of heavy land degradation and water pollution in karst areas. Thus, the geological and geomorphological framework of the country determines the environmental problems that should be managed for an adequate protection of karstic areas.

\section{Acknowledgements}

We thank Islamic Azad University, Mashhad branch for its generous support of the project.

\section{References}

[1] Bagherzadeh A, Mansouri Daneshvar MR (2011). Sediment yield assessment by EPM and PSIAC models using GIS data in semi-arid region. Frontiers of Earth Science 5(2), 207-216.

[2] Bakalowicz M (2005). Karst groundwater: a challenge for new resources. Hydrogeology Journal 13(1), 148-160.

[3] Calò F, Parise M (2006). Evaluating the human disturbance to karst environments in southern Italy. Acta Carsologica $35(2-3), 47-56$.

[4] Calò F, Parise M (2009). Waste management and problems of groundwater pollution in karst environments in the context of a post-conflict scenario: The case of Mostar (Bosnia Herzegovina). Habitat International 33(1), 63-72.

[5] Daly D, Dassargues A, Drew D, Dunne S, Goldschneider N, Neale S,Popescu IC, Zwahlen F (2002). Main concepts of the "European approach" to karst-groundwater-vulnerability assessment and mapping. Hydrogeology Journal 10(2), 340-345.

[6] Das BK, Kaur P (2001). Major ion chemistry of Renuka Lake and weathering processes, Sirmaur District, Himachal Pradesh, India. Environmental Geology 40(7), 908-917.

[7] Drew D, Hötzl H (1999). Karst hydrogeology and human activities: impacts, consequences and implications. International Contributions to Hydrogeology 20. A.A. Balkema, Rotterdam. 322 p.

[8] Emmett AJ, Telfer AL (1994). Influence of karst hydrology on water quality management in southeast South Australia. Environmental Geology 23(2) 149-155.

[9] Ford DC (1993). Environmental change in karst areas. Environmental Geology 21(3), 107-109.
[10] Gabrovsek F, Romanov D, Dreybrodt W (2004). Early karstification in a dual-fracture aquifer: the role of exchange flow between prominent fractures and a dense net of fissures. Journal of Hydrology 299(1-2), 45-66.

[11] Gutiérrez F, Johnson KS, Cooper AH (2008). Evaporite karst processes, landforms, and environmental problems. Environmental Geology 53(5), 935-936.

[12] Johnson KS, Neal JT (2003). Evaporite karst and engineering/environmental problems in the United States. Oklahoma Geological Survey Circular 109, 353 p.

[13] Kovačič G, Ravbar N (2005). A review of the potential and actual sources of pollution to groundwater in selected karst areas in Slovenia. Natural Hazards and Earth System Sciences 5, 225-233.

[14] León LM, Parise M (2009). Managing environmental problems in Cuban karstic aquifers. Environmental Geology 58(2), 275-283.

[15] Liedl R, Sauter M, Hückinghaus D, Clemens T, Teutsch G (2003). Simulation of the development of karst aquifers using a coupled continuum pipe flow model. Water Resources Research 39(3), DOI: 10.1029/2001WR001206.

[16] Milanović P (2000). Geological Engineering in Karst. Zebra Publishing Ltd, Belgrade. 347 p.

[17] North LA, Van Beynen PE, Parise M (2009). Interregional comparison of karst disturbance: West-central Florida and southeast Italy, Journal of Environmental Management 90(5) $1770-1781$.

[18] Parise M, Gunn J (2007). Natural and Anthropogenic Hazards in KarstAreas: Recognition, Analysis and Mitigation 279. Geological Society, London. Special Publication, 205 p.

[19] Parise M, Qiriazi P, Sala S (2004). Natural and anthropogenic hazards in karst areas of Albania. Natural Hazards and Earth System Sciences 4, 569-581.

[20] Parise M, Qiriazi P, Sala S (2008). Evaporite karst of Albania: main features and cases of environmental degradation. Environmental Geology 53(5), 967-974.

[21] Van Beynen P, Townsend K (2005). A disturbance index for karst environments. Environmental Management 36(1), 101-116.

[22] Van Beynen P, Feliciano N, North L, Townsend K (2007). Application of the karst disturbance index in Hillsborough County, Florida. Environmental Management 39(2), 261-277.

[23] White WB (2006). Fifty years of karst hydrology and hydrogeology: 1953-2003. Geological Society of America Special Papers 404, 139-152. 